\title{
Kegiatan Perekonomian
}

Enny Wati, SE., M.Si

ennywati75@gmail.com 



\section{Definisi IImu Ekonomi}
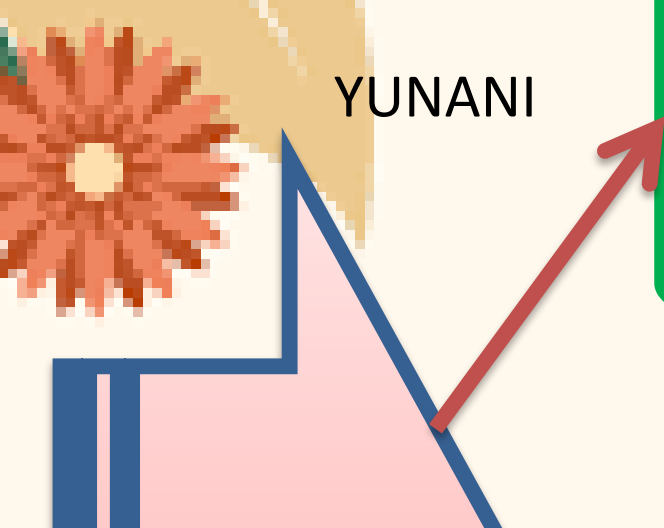

Oikos : Rumah Tangga Nomos : Aturan

\section{siapa diri kita (manusia)}

ilmu yang mempelajari perilaku individu dan masyarakat dalam menentukan pilihan untuk menggunakan sumber daya-sumber daya yang langka dalam upaya meningkatkan kualitas hidupnya 


\section{Masalah-masalah Pokok Ekonomi}

SD Terbatas Kebutuhan Tidak Terbatas 
suatu usaha untuk memperoleh hasil semaksimal mungkin dengan melakukan pengorbanan seminim/ sekecil mungkin

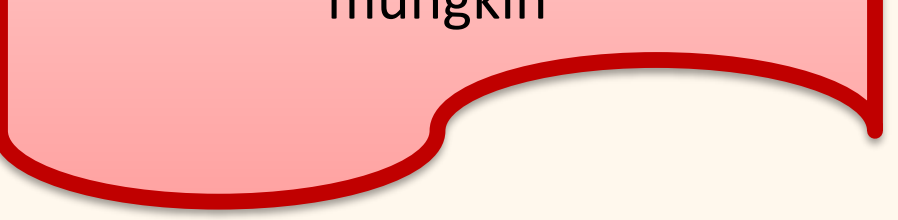

\section{Kegiatan Distribusi,}

- bagaimana menyalurkan barang dan jasa dari produsen kepada konsumen. Contohnya sarana distribusi yang murah

\section{Kegiatan konsumsi,}

\section{Sistem Ekonomi}

1. Tradisional

2. Komando/terencana

3. Pasar

4. Campuran

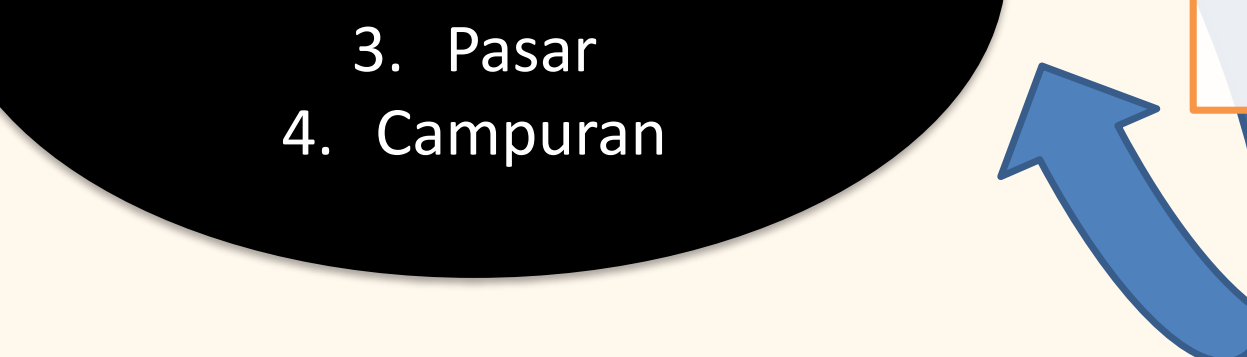

- bagaimana memperoleh kepuasaan sebesarbesarnya dari suatu barang atau jasa dengan pengorbanan dan penggunaan anggaran tertentu. Contohnya membeli barang atau jasa berkualitas dengan harga yang murah 


\section{Ciri-Ciri Penerapan Prinsip} Ekonomi

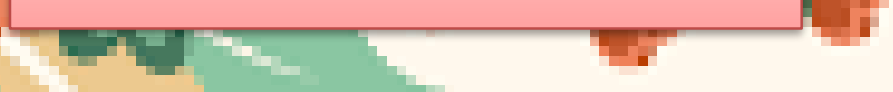

Bertindak rasional
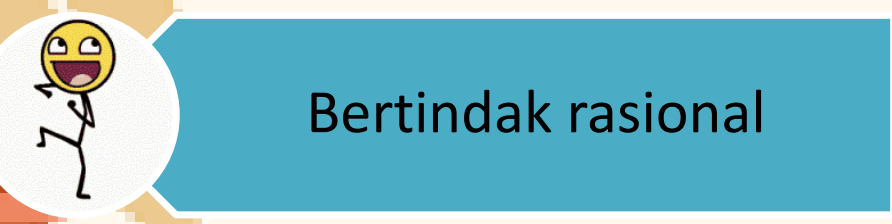

Bertindak ekonomis

Bertindak hemat

Membuat skala prioritas,

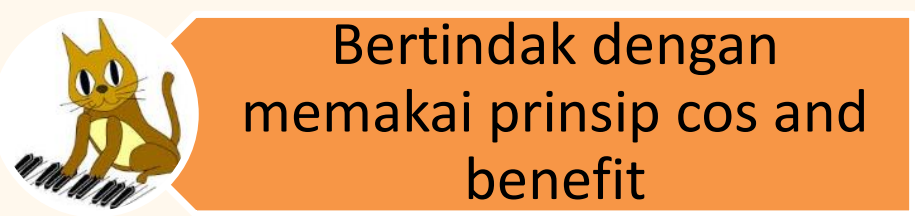

\section{Tujuan Prinsip Ekonomi}
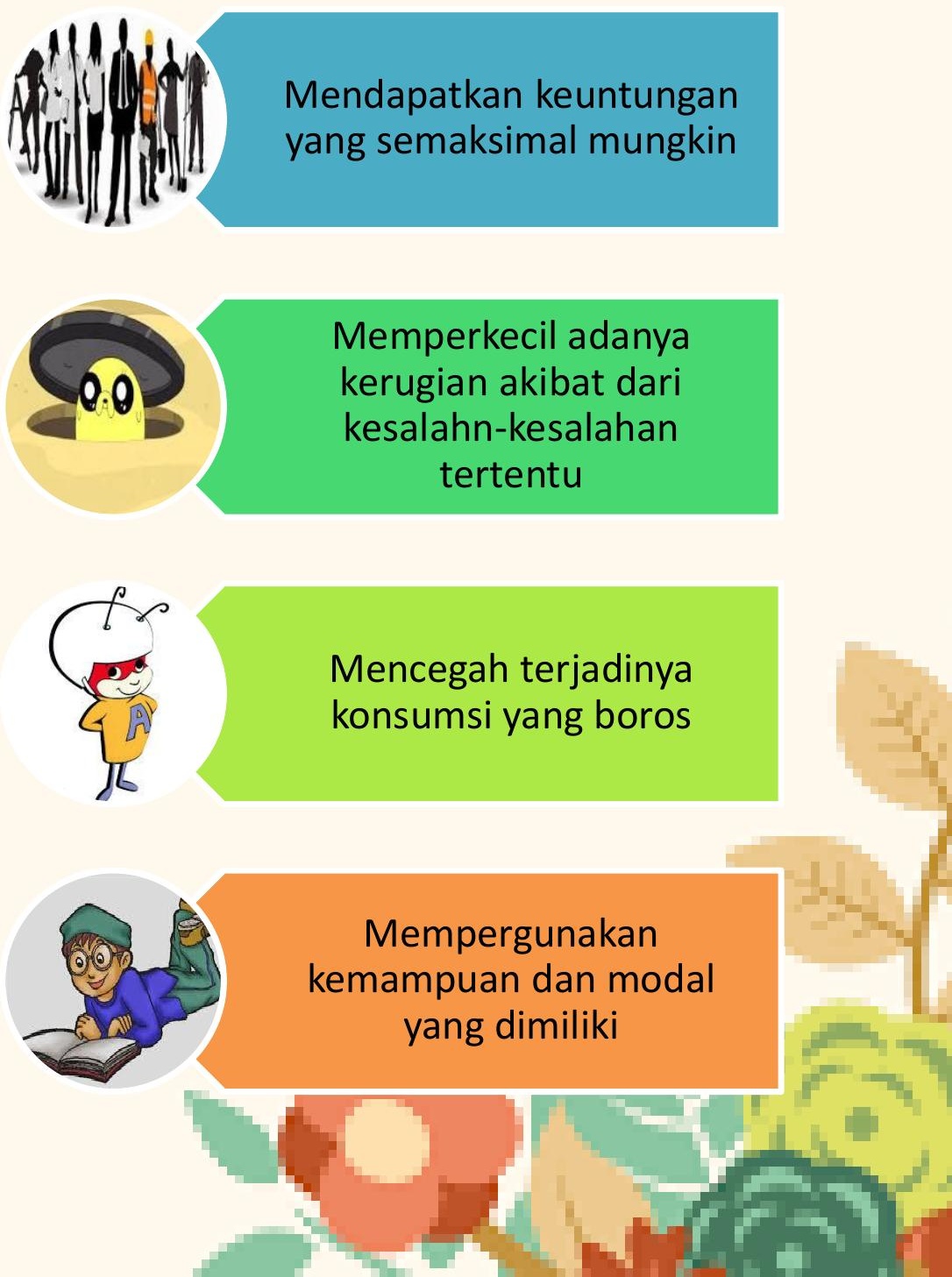


\section{Manfaat IImu Ekonomi}

\section{Membantu dalam pengambilan keputusan}

- Kelangkaan mengharuskan individu dan kelompok untuk mengambil keputusan yang efektif dan efisien

\section{Membantu memahami perilaku individu dan}

masyarakat

- Manusia adalah makhluk social yang tidak dapat hidup tanpa orang lain. Didalam memenuhi kebutuhannya individu maupun kelompok memiliki cara yang berbedabeda. Interaksi antar individu melalui pertukaran (pasar)n dalam upaya menangani kelangkaan.

Membantu memahami masalah-masalah ekonomi yang dihadapi baik nasional maupun internasional

- Kelangkaan yang dihadapi bukan hanya pada tingkatan individu tetapi juga dihadapi pada tingkat internasional

\section{Bermanfaat dalam membangun masyarakat demokrasi}

- Demokrasi dapat memperbaiki proses alokasi sumber daya karena mencerminkan aspirasi masyarakat 


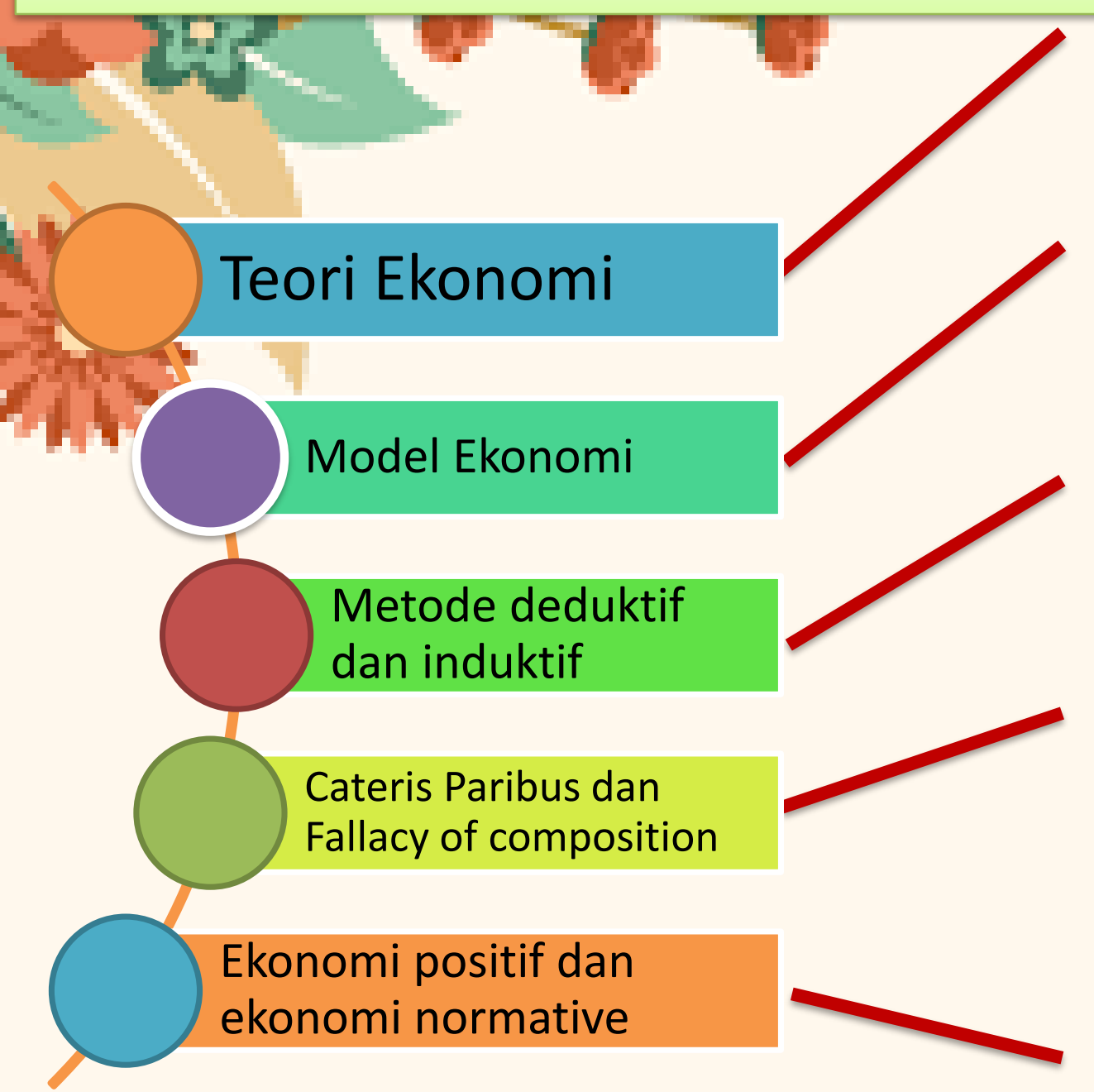

Teori adalah pernyataan atau sekumpulan pernyataan tentang sebab akibat, aksi-reaksi

verbal (menggunakan kata-kata), diagramatis dan matematis

pengambilan kesimpulan dari umum ke khusus (deduktif) dan dari khusus ke umum (induktif)

CP bermakna factor-faktor lain dianggap tetap

FOC bermakna apa yang baik dalam skala kecil belum tentu baik dalam skala besar

Positif = Menerangkan hal akan terjadi dengan membandingkan dengan peristiwa yang sebenarnya terjadi. Normative $=$ mengemukakan pendapat apa yang sebaiknya harus terjadi 
Bagian dari ilmu ekonomi yang menganalisis bagian kecil dari kegiatan perekonomian
Menganalisis keseluruhan kegiatan perekonomian bersifat global dan tidak memperhatikan kegiatan ekonomi yang dilakukan unit-unit kecil dalam perekonomian

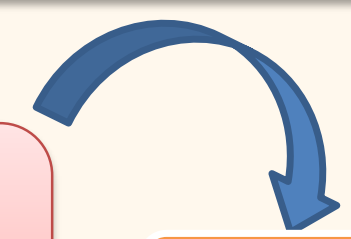

Ekonomi mikro
Interaksi dipasar barang

Tingkah laku pembeli dan penjual

Interaksi di pasar factor produksi

Penentuan tingkat kegiatan perekonomian Negara (pendapatan nasional).

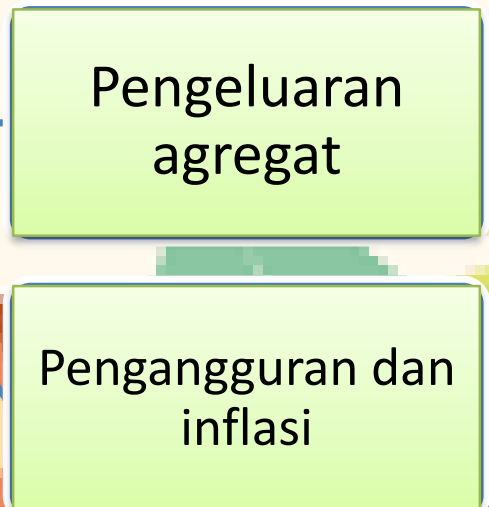


- Prathama Rahardja dan Mandala Manurung. 2018. Pengantar Ilmu Ekonomi (Mikro ekonomi dan Makroekonomi) Edisi Ketiga. Jakarta. FE UI

- Nopirin. 2000. Pengantar Ilmu Ekonomi Makro \& Mikro Edisi Pertama. Yogyakarta. BPFE 


$$
\text { xhank }
$$

